\title{
Immunomodulating Therapies in Breast Cancer- From Prognosis to Clinical Practice
}

\author{
Marcus Schmidt* (D) and Anne-Sophie Heimes
}

check for updates

Citation: Schmidt, M.; Heimes, A.-S. Immunomodulating Therapies in Breast Cancer-From Prognosis to Clinical Practice. Cancers 2021, 13, 4883. https://doi.org/10.3390/ cancers 13194883

Academic Editor: David Wong

Received: 1 September 2021

Accepted: 26 September 2021

Published: 29 September 2021

Publisher's Note: MDPI stays neutral with regard to jurisdictional claims in published maps and institutional affiliations.

Copyright: (c) 2021 by the authors Licensee MDPI, Basel, Switzerland. This article is an open access article distributed under the terms and conditions of the Creative Commons Attribution (CC BY) license (https:/ / creativecommons.org/licenses/by/ $4.0 /)$.
Department of Obstetrics and Gynecology, University Medical Center Mainz, 55131 Mainz, Germany; anne-sophie.heimes@unimedizin-mainz.de

* Correspondence: marcus.schmidt@unimedizin-mainz.de; Tel.: +49-61-3117-3291

Simple Summary: The role of the immune system in breast cancer has been debated for decades. It is generally accepted that tumor-infiltrating lymphocytes are associated with positive prognostic and predictive effects, especially in triple negative breast cancer. This subset of breast cancer is characterized by the absence of hormone receptors and human epidermal growth factor receptor 2 . Compared to other breast cancer subtypes, triple-negative breast cancer has more mutations and neoantigens, making it more immunogenic. Releasing the brakes on the immune system with the help of so-called immune checkpoint inhibitors leads to activation of the immune system and destruction of cancer cells. This, in turn, improves survival, especially in early and advanced triple-negative breast cancer. A new and promising strategy is the enhancement of the immune response using individualized mRNA vaccines against tumor-specific neoantigens.

Abstract: The role of the immune system in breast cancer has been debated for decades. The advent of technologies such as next generation sequencing (NGS) has elucidated the crucial interplay between somatic mutations in tumors leading to neoantigens and immune responses with increased tumor-infiltrating lymphocytes and improved prognosis of breast cancer patients. In particular, triple-negative breast cancer (TNBC) has a higher mutational burden compared to other breast cancer subtypes. In addition, higher levels of tumor-associated antigens suggest that immunotherapies are a promising treatment option, specifically for TNBC. Indeed, higher concentrations of tumor-infiltrating lymphocytes are associated with better prognosis and response to chemotherapy in TNBC. An important target within the cancer immune cell cycle is the "immune checkpoint". Immune checkpoint inhibitors (ICPis) block the interaction of certain cell surface proteins that act as "brakes" on immune responses. Recent studies have shown that ICPis improve survival in both early and advanced TNBC. However, this comes at the price of increased toxicity, particularly immune-mediated toxicity. As an alternative approach, individualized mRNA vaccination strategies against tumor-associated neoantigens represent another promising approach leading to neoantigen-specific immune responses. These novel strategies should help to improve treatment outcomes, especially for patients with triple negative breast cancer.

Keywords: tumor infiltrating lymphocytes (TILs); immune checkpoint inhibitors (ICPis); mRNA vaccine; tumor-associated antigens (TAA); neoantigens

\section{Introduction}

Breast cancer is the most common cancer and the leading cause of cancer death for women worldwide [1]. In 2015, breast vancer incidence was 2.4 million, with 523,000 breast cancer deaths. Invasive breast cancer can be divided in several molecular subgroups (e.g., luminal A, luminal B, HER2-positive and triple-negative) which have different prognoses and different systemic therapeutic options (e.g., chemotherapy, endocrine therapy, anti-HER2 therapy) [2]. Early breast cancer has no distant metastases and is curable [2]. However, if distant metastases occur, the disease is treatable but incurable [3]. 
The role of the immune system in breast cancer has long been debated [4]. With the advent of modern techniques, such as mRNA sequencing data from The Cancer Genome Atlas (TCGA), it has been shown that high expression of T-cell and B-cell signatures predicts improved overall survival in many tumor types, including breast cancer [5]. In particular, triple-negative breast cancer (TNBC), which has a more pronounced immunogenic potential compared to other molecular subtypes, is of great interest. TNBC accounts for up to $20 \%$ of breast cancers and is associated with a significantly worse prognosis in the first 2 to 3 years after diagnosis compared with other breast cancer subtypes [6]. It is now generally accepted that TNBC is not a homogeneous disease. Instead, TNBC consists of multiple subtypes (e.g., basal-like 1 and 2, immunomodulatory, mesenchymal, mesenchymal stem-like, and luminal androgen receptor) [7]. In a comprehensive immunogenomic analysis of over 10,000 tumors using TCGA data, Thorsson and co-workers identified six stable and reproducible immune subtypes C1-C6 (i.e., wound-healing, IFN- $\gamma$-dominant, inflammatory, lymphocyte-depleted, immunologically quiet, and TGF- $\beta$-dominant) [8]. Interestingly, these immune subtypes include multiple tumor types, and are characterized by a dominance of either macrophage or lymphocyte signatures, T-helper phenotype, extent of intratumoral heterogeneity, and proliferative activity. Although these authors did not comment specifically on TNBC, it is likely that TNBC with a strong lymphocytic infiltrate belong to immune subtype C3. Using even more sophisticated techniques, such as single-cell sequencing, Wu and his collaborators have deconvoluted breast cancer cohorts and stratified them into nine clusters, called "ecotypes", with unique cellular compositions and clinical outcomes that provide a comprehensive transcriptional atlas of breast cancer cellular architecture [9]. Significantly more somatic mutations and neoantigens are detected in TNBC than in other molecular subtypes, resulting in increased immunogenicity [10]. In a systematic review, Stanton and colleagues showed that the extent of tumor-infiltrating lymphocytes (TILs) varies within and between breast cancer subtypes, with TNBC having numerous TILs [11]. This may identify breast cancers that are more suitable for immunotherapy.

\section{Brief Overview of the Immune System in Breast Cancer}

The role of the immune system in the breast cancer microenvironment is ambiguous. Following the presentation of antigens by antigen-presenting cells (APCs), various immune system responses may occur. On the one hand, tumor-inhibitory acute inflammation may develop, driven by type 1 T helper cells (Th1) via CD8 lymphocytes, B cells, or M1 macrophages. On the other hand, tumor-promoting Th2-driven chronic inflammation can also occur through M2 macrophages, regulatory T cells (Tregs), or immune checkpoints, such as programmed cell death protein 1 (PD-1) or its ligand programmed cell death 1 ligand 1 (PD-L1). In addition, bone-marrow-derived cells, such as myeloidderived suppressor cells and mesenchymal stromal cells, can exert pro-tumorigenic effects through negative regulation of immune responses. Originally, it was thought that Th1 and Th2 cells are characterized by their mutually exclusive expression patterns of cytokines. Th1 cells produce IFN- $\gamma$, whereas Th2 cells produce IL-4, IL-5 and IL-13 [12]. Recent results, however, have shown that a single-cytokine-based nomenclature fails to capture the complexity and diversity of T helper cells [13]. Immunoediting, the dynamic interaction between the immune system and the tumor, leads to different stages of tumor evolution (elimination-equilibrium-escape) $[14,15]$. This process is responsible for both eliminating tumors and sculpting the immunogenic phenotypes of tumors that eventually form in immunocompetent hosts in the early phase of breast cancer development. The acute inflammatory response creates a T helper (Th) type 1 microenvironment at the tumor site, leading to an immune response that is tumor-suppressive and destroys tumor cells. Tumor cell variants, however, can escape the immune response. This immunoediting creates a state of equilibrium. When inflammation transitions from acute to chronic, a Th type 2 profile develops, leading to tumor-promoting effects with escape from the immune system and uncontrolled tumor growth (Figure 1). 


\section{Elimination}

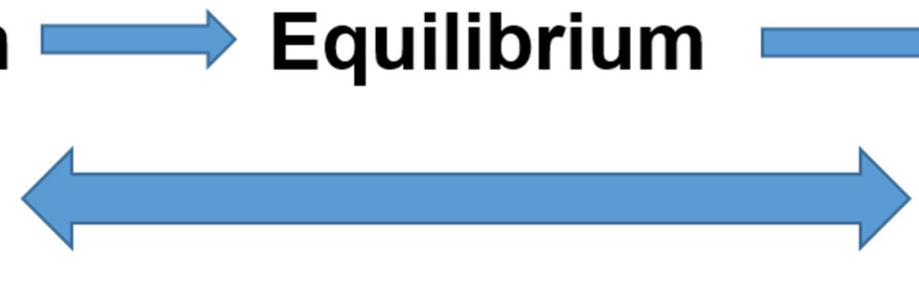

Escape

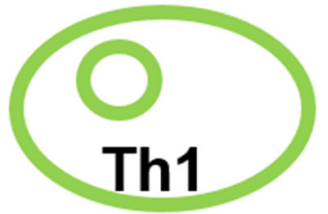

Th type 1 -

Tumor-suppressive
Th type 2 Tumor-promoting

Figure 1. Immunoediting in breast cancer. Cancer immunoediting has dual host-protecting and tumor-sculpting actions of the immune system that not only prevent but also shape neoplastic disease. Cytokines determine T-cell polarization. Th1 and Th2 cells are characterized by their mutually exclusive expression patterns of cytokines. Th1 cells produce IFN- $\gamma$, whereas Th2 cells produce IL-4, IL-5, and IL-13. The presence of IL-12 and/or interferon- $\gamma$ drives previously uncommitted T cells to become polarized to produce T1 cytokines, while IL-4 drives them to become polarized to secrete T2 cytokines. This, in turn, leads to either a tumor-suppressive or a tumor-promoting microenvironment. Abbreviations: Th, T helper cells.

\section{Prognostic and Predictive Significance of Tumor-Infiltrating Lymphocytes}

Most studies that addressed the prognostic and/or predictive role of TILs in breast cancer focused on the cellular immune system, particularly cytotoxic T cells [16-21]. Overall, these studies showed that increased rates of tumor-infiltrating lymphocytes or T-cell transcripts were associated with improved prognosis in rapidly proliferating breast cancer such as TNBC.

In contrast, we primarily examined B cells and the humoral immune system and reported a strong positive prognostic impact of a $\mathrm{B}$ cell metagene on breast cancer prognosis [22]. This strong protective effect of a B cell/plasma cell signature was later confirmed by others $[23,24]$. Tumor-infiltrating plasma cells were identified by confocal microscopy as the source of immunoglobulin kappa C (IGKC) expression [25]. In this study, co-staining with anti-human IgG showed that IGKC was expressed in IgG-positive cells, a known feature of B-cell maturation and plasma cell differentiation after antigen contact. IGKC has been associated with favorable prognosis in untreated patients and with response to anthracycline-containing neoadjuvant chemotherapy in early breast cancer [25]. Indeed, in a comprehensive analysis of the prognostic landscape of genes and infiltrating immune cells in human cancers, Gentles et al. confirmed that plasma cell signatures, as well as plasma cells expressing IGKC, are associated with improved survival [24]. However, the strong dependence of the humoral immune system on $\mathrm{T}$ cells is examplified by $\mathrm{C}-\mathrm{X}-\mathrm{C}$ motif chemokine ligand 13 (CXCL13)-positive CD4+ follicular helper T (Tfh) cells, which are crucial for germinal center development and antigen-specific $\mathrm{B}$ cell maturation to high-affinity memory cells and antibody-secreting plasma cells [26]. In addition, CXCL13 has been associated with improved survival in TNBC [27].

Overall, these and other findings suggest that humoral immunity may be as important as cellular immunity in eliminating cancer [28]. These, initially retrospective, results were later confirmed in exploratory studies using archival tissue from randomized trials $[27,29,30]$, as well as by histological evidence of TILs in archival tissue from randomized trials [19,31,32]. Recently, in the neoadjuvant EXPRESSION trial, we demonstrated that genes with significantly higher expression in pathologically complete responders are primarily related to the immune response, including immunoglobulins [33]. These results also support the predictive role of the humoral immune system in early breast cancer.

Particularly in triple-negative breast cancer, there is a strong association between TILs and a more favorable prognosis or response to neoadjuvant chemotherapy [31,32,34-37]. Overall, increased tumor-infiltrating lymphocytes in TNBC resulted in increased complete pathologic response (pCR) and also improved survival (Table 1). 
Table 1. Tumor-infiltrating lymphocytes in early triple-negative breast cancer.

\begin{tabular}{|c|c|c|c|c|c|}
\hline Author & $n$ & pCR & DDFS & DFS & OS \\
\hline Denkert et al., 2015 [30] & 314 & $\begin{array}{c}33.8 \% \text { vs. } 59.9 \% \\
p=0.004\end{array}$ & - & - & - \\
\hline Denkert et al., 2018 [31] & 906 & $\begin{array}{c}11 \% \text { vs. } 50 \% \\
p<0.0001\end{array}$ & - & HR $0.93(0.87-0.98)$ & HR $0.92(0.86-0.99)$ \\
\hline Loi et al., 2014 [32] & 134 & - & HR 0.77 (0.61-0.98) & & - \\
\hline Adams et al., 2014 [34] & 506 & - & - & HR $0.86(0.76-0.98)$ & HR $0.82(0.68-0.99)$ \\
\hline Hida et al., 2019 [37] & 234 & $\begin{array}{c}21 \% \text { vs. } 46 \% \\
p=0.032\end{array}$ & - & HR 3.71 (1.60-8.57) & HR 3.87 (1.46-10.27) \\
\hline Ibrahim et al., 2014 [36] & 2987 & - & HR $0.78(0.68-0.90)$ & HR $0.70(0.56-0.87)$ & HR 0.66 (0.53-0.83) \\
\hline Loi et al., 2013 [35] & 512 & - & . & HR $0.31(0.11-0.84)$ & HR 0.30 (0.094-0.95) \\
\hline
\end{tabular}

This significant association of tumor-infiltrating immune cells and TNBC is not surprising, considering that the overall mutational burden is highest in TNBC [10]. In addition, these authors found that mutational burden was highly correlated with neoepitope load $(\mathrm{R} 2=0.86)$. A comprehensive analysis of immunogenic signatures in TNBC based on two sets of large-scale breast cancer genomic data showed that TNBC has the strongest immunogenicity among breast cancer subtypes [38]. Furthermore, these authors confirmed that TNBC also has higher levels of immune cell infiltration and higher expression of genes encoding immune checkpoints than non-TNBC. However, mutational and neoantigen load appear to incompletely explain the immune response in TNBC, as other studies have described an inverse relationship between immune infiltration and somatic copy number alterations [39,40]. Obviously, the exact relationship between immune infiltration, mutation burden, and neoantigen burden has not been fully elucidated. Nevertheless, TILs are widely used, especially in TNBC. To improve reproducibility, a standardized method for the evaluation of TILs has been defined to integrate this parameter into standard histopathological practice [41,42].

\section{Immune Checkpoint Inhibitors}

Important target structures in the immune system are "immune checkpoints". Immune checkpoint inhibitors (ICPis) block the interaction of certain cell surface proteins that serve as "brakes" on immune responses. Currently, the most important immune checkpoint in breast cancer is the PD-1/PD-L1 axis [43,44]. The interaction between PD-1 and its ligand PD-L1 functions as an immune checkpoint against unrestrained cytotoxic $\mathrm{T}$ effector cell activity. Furthermore, it promotes peripheral $\mathrm{T}$ effector cell exhaustion and conversion of $\mathrm{T}$ effector cells to immunosuppressive Tregs [45]. Immune checkpoint inhibitors that block the PD-1/PD-L1 axis and reactivate cytotoxic T effector cell function increase immune cell activity against tumor cells.

Indeed, monoclonal antibodies, so-called immune checkpoint inhibitors, which block either PD-1 or PD-L1 (e.g., atezolizumab, durvalumab, nivolumab, or pembrolizumab) are increasingly used to release the "brake" of the immune system and, thus, increase the activity of the immune system against the tumor. A potential problem is that ICPis require the presence of effector immune cells in the tumor, suggesting a baseline immune response to trigger pre-existing immunity [46]. The monoactivity of ICPis such as atezolizumab or pembrolizumab was modest in phase I trials in advanced and extensively pretreated TNBC [15]. Few, but long-lasting, responses were observed, particularly in less extensively pretreated patients [47]. In a phase III trial (KEYNOTE-119) in pretreated advanced TNBC, monotherapy with pembrolizumab did not significantly improve overall survival compared with chemotherapy, although the effect of pembrolizumab treatment increased with increasing PD-L1 positivity [48]. However, the efficacy can be significantly 
increased by adding chemotherapy. Indeed, chemotherapy may lead to immunogenic cell death, which in turn activates the antitumor immune response $[49,50]$. The combination of immunotherapy and chemotherapy should, therefore, achieve an additive or synergistic clinical effect [51].

Due to the specific mode of action of immunotherapies, which, in contrast to cytotoxic chemotherapy, have no direct effect on tumor cell proliferation, a therapeutic response can only be expected at a later stage. In addition, infiltration of immune cells may lead to an initial enlargement of metastases, a so-called pseudoprogression [52]. However, this pseudoprogression occurs in less than $10 \%$ of cases, whereas, conversely, a very rapid increase in size, known as hyperprogression, may be more common occuring in up to $29 \%$ [53]. Therefore, continuation of therapy with ICPi in the presence of imaging evidence of progression should only be considered if the clinical condition has improved and no treatment-related toxicities are present [54].

\subsection{ICPi in Advanced Breast Cancer}

The monoactivity of ICPis such as atezolizumab or pembrolizumab in advanced TNBC has been evaluated in several phase I and phase II studies (Table 2). Depending on PD-L1 status and line of therapy, objective response rates (ORR) ranged from 5.3\% to $24 \%$. Progression-free survival (PFS) ranged from 1.4 to 2.1 months and overall survival (OS) ranged from 9.0 to 18 months [47,55-57]. Winer and colleagues compared pembrolizumab with chemotherapy for second- or third-line treatment of patients with metastatic triplenegative breast cancer [58]. Randomization was stratified by PD-L1 tumor status (combined positive score [CPS $\geq 1$ ] vs. negative [CPS $<1]$ ) and history of prior neoadjuvant or adjuvant treatment vs. de novo metastatic disease at initial diagnosis. The median overall survival in patients with a PD-L1 CPS of 1 or more was 10.7 months in the pembrolizumab group and 10.2 months in the chemotherapy group (hazard ratio [HR] 0.86; 95\% confidence interval [95\% CI] 0.69-1.06). The efficacy of pembrolizumab increased with higher CPS. However, no significant improvement was observed.

The above-mentioned studies enrolled patients with advanced TNBC. Very few earlyphase clinical trials have included advanced hormone receptor (HR)-positive and HER2negative patients. Either with an ICPi alone or in combination, the survival was modest [49-52].

It is obvious that further combinations are needed to increase the efficacy of ICPi in breast cancer. For instance, low-dose metronomic chemotherapy with cyclophosphamide reduced regulatory T cells (Tregs) and enhanced anti-tumor activity of cytotoxic T cells [59]. In addition, vinorelbine, cyclophosphamide, and 5-FU had significant preclinical effects on circulating and tumour-infiltrating immune cells and could be used to obtain synergy with anti-PD-L1 [60]. Furthermore, a combinatorial therapy in preclinical models of breast cancer increased checkpoint inhibition by activating antigen-presenting cells, enhancing intratumoral CD8+ T cells, and increasing progenitor exhausted CD8+ T cells [61]. Radiation therapy also has immunomodulatory effects that could contribute to increased efficacy of immunotherapies [62].

Although preclinical models provide a solid basis that certain low-dose chemotherapies, such as cyclophosphamide or vinorelbine, improve anti-PD-L1 activity in breast cancer, these therapeutic approaches need to be tested in clinical trials. In the adaptive, non-comparative phase II TONIC trial, Voorwerk and coworkers investigated multiple strategies (e.g., radiation, low-dose cyclophosphamide, cisplatin, doxorubicin) to make the tumor microenvironment more sensitive to PD-1 blockade with nivolumab in 67 patients with advanced TNBC [63]. In the entire cohort, the objective response rate (ORR) was $20 \%$. Most responses were seen in the doxorubicin (35\%) and cisplatin $(23 \%)$ cohorts. Interestingly, the authors noted upregulation of immune-related genes in these two cohorts and speculated that this induction approach may induce a more favorable tumor microenvironment and increase the likelihood of response to PD-1 blockade in TNBC. 
Another approach to increase the efficacy of an immune checkpoint blockade in advanced cancer is to combine it with poly(ADP-ribose) polymerase inhibitors (PARPi). PARPi-mediated unrepaired DNA damage modulates the tumor immunological microenvironment through a number of molecular and cellular mechanisms, such as increasing genomic instability, immune pathway activation, and PD-L1 expression on cancer cells, which could promote responsiveness to ICPis [64]. In the MEDIOLA basket study, durvalumab and olaparib were combined in solid tumors [65]. This combination showed promising antitumor activity and safety. Disease was under control at 12 weeks in 24 of 30 evaluable patients $(80 \%)$. While the above combinations are interesting and promising, combining ICPi with chemotherapy is currently the simplest approach. A phase Ib study evaluated the safety and clinical activity of atezolizumab in combination with nanoparticulate albumin-bound (nab)-paclitaxel in a cohort of 33 extensively pretreated patients with advanced TNBC [66]. The rationale for combining an immune checkpoint inhibitor with chemotherapy was the postulated greater activation of T-cell-mediated immunity due to increased release of tumor-associated antigens and resulting immunogenic cell death [51]. The results of the study demonstrated that the combination of ICPi and nab-paclitaxel is an effective treatment option with a tolerable side effect profile for patients with metastatic TNBC (Table 2).

Table 2. Phase I/II evidence for ICPis in advanced breast cancer.

\begin{tabular}{|c|c|c|c|c|c|c|}
\hline Author & $n$ & Therapy & AE & ORR & PFS & OS \\
\hline Emens et al., 2019 [56] & $\begin{array}{c}116 \\
\text { TNBC }\end{array}$ & Atezolizumab & $63 \%$ & $24 \%$ & $1.4 \mathrm{~m}$ & $17.6 \mathrm{~m}$ \\
\hline Nanda et al., 2016 [57] & $\begin{array}{c}31 \\
\text { TNBC }\end{array}$ & Pembrolizumab & $66.3 \%$ & $18.5 \%$ & $1.9 \mathrm{~m}$ & $11.2 \mathrm{~m}$ \\
\hline Adams et al., 2019 [55] & $\begin{array}{c}170 \\
\text { TNBC }\end{array}$ & Pembrolizumab & $60.6 \%$ & $5.3 \%$ & $2.0 \mathrm{~m}$ & $9.0 \mathrm{~m}$ \\
\hline Adams et al., 2019 [47] & $\begin{array}{c}84 \\
\text { TNBC }\end{array}$ & Pembrolizumab & $63.1 \%$ & $21.4 \%$ & $2.1 \mathrm{~m}$ & $18.0 \mathrm{~m}$ \\
\hline Adams et al., 2019 [66] & $\begin{array}{c}33 \\
\text { TNBC }\end{array}$ & Atezolizumab + nab-paclitaxel & $100 \%$ & $39.4 \%$ & $5.5 \mathrm{~m}$ & $14.7 \mathrm{~m}$ \\
\hline Barroso-Sousa et al., 2020 [67] & $\begin{array}{c}8 \\
\mathrm{HR}+\end{array}$ & Pembrolizumab + radiotherapy & $87.5 \%$ & 0 & $1.4 \mathrm{~m}$ & $2.9 \mathrm{~m}$ \\
\hline Pérez-García et al., 2020 [68] & $\begin{array}{c}44 \\
\mathrm{HR}+\end{array}$ & Pembrolizumab + eribulin & & $18 \%$ & $6.0 \mathrm{~m}$ & - \\
\hline Yuan et al., 2021 [69] & $\begin{array}{c}23 \\
\mathrm{HR}+\end{array}$ & Pembrolizumab + palbociclib + letrozole & & $56 \%$ & $25.2 \mathrm{~m}$ & $36.9 \mathrm{~m}$ \\
\hline
\end{tabular}

Abbreviations: AE, adverse events; HR, hormine receptor; ICPis, immune checkpoint inhibitors; $\mathrm{m}$, months; ORR, objective response rate; OS, overall survival; PFS, progression-free survival; TMBC, triple-negative breast cancer; vs., versus.

Building on these encouraging results, the phase III IMpassion130 trial confirmed the clinical efficacy of atezolizumab in combination with nab-paclitaxel as a first-line therapy in a cohort of 902 patients with metastatic or locally advanced TNBC [70]. Patients were randomized 1:1 to either the experimental arm (atezolizumab in combination with nabpaclitaxel) or the placebo arm (nab-paclitaxel + placebo). The results showed a significant prolongation of PFS in both the intention-to-treat (ITT) population and the PD-L1-positive subgroup: PFS was 7.2 months in the experimental arm compared with 5.5 months in the placebo arm (HR 0.80; 95\% CI 0.69-0.92; $p=0.002)$. In the subset of PD-L1-positive ( $\geq 1 \%$ of immune cells) TNBC patients, PFS was 7.5 months compared with 5 months in the placebo arm. Atezolizumab in combination with nab-paclitaxel prolonged OS in PD-L1-positive patients (25.0 versus 15.5 months). Based on these results, atezolizumab in combination with nab-paclitaxel is now approved as a first-line therapy for advanced PD-L1-positive TNBC. In a recent IMpassion130 update, Schmid et al. showed that atezolizumab did not 
significantly increase OS in the overall cohort from 18.7 to 21 months at longer followup (HR 0.86; 95\% CI 0.72-1.02; $p=0.078$ ) [71]. However, in PD-L1-positive patients, OS increased from 18 to 25 months (HR 0.71; 95\% CI 0.54-0.94). Surprisingly, the recently presented IMpassion131 trial combining atezolizumab with conventional paclitaxel in advanced TNBC did not improve PFS or OS compared with placebo + paclitaxel [72]. Of 651 randomized patients, $45 \%$ had PD-L1-positive aTNBC. In the PD-L1-positive population, atezolizumab and paclitaxel were associated with a more favorable unconfirmed overall response rate ( $63 \%$ vs. $55 \%$ for placebo-paclitaxel) and a longer median duration of response (7.2 and 5.5 months, respectively). Possible reasons for this apparent contrast with the benefit observed in IMpassion130 require further investigation, although several hypotheses (e.g., different taxanes and the role of steroids or imbalances in prognostic features or random results in a relatively small study) are under discussion [72,73].

Recently, Cortes and coworkers presented the results of KEYNOTE-355, a randomized, double-blind, phase III trial of pembrolizumab + chemotherapy versus placebo + chemotherapy in previously untreated, locally recurrent, unresectable, or metastatic triple-negative breast cancer [74]. They showed that pembrolizumab in combination with multiple chemotherapy partners (nab-paclitaxel, paclitaxel, or gemcitabine/carboplatin) produced a statistically significant and clinically meaningful improvement in PFS compared with chemotherapy alone in patients with previously untreated locally recurrent unresectable or metastatic TNBC whose tumors expressed PD-L1. Compared with TNBC, there are few randomized data in hormone receptor (HR)-positive/HER2-negative advanced breast cancer. Tolaney et al. randomized 88 heavily pretreated patients with advanced HR-positive/HER2-negative breast cancer to eribulin $+/-$ pembrolizumab in one study. [75]. However, the addition of pembrolizumab to eribulin did not improve PFS or OS compared to eribulin alone in either the intention-to-treat or PD-L1-positive populations. The results of randomized trials in advanced TNBC are summarized in Table 3:

Table 3. Randomized evidence for ICPi in advanced breast cancer.

\begin{tabular}{|c|c|c|c|c|}
\hline Author & $n$ & Therapy & PFS in ITT & OS in ITT \\
\hline Schmid et al., 2018 [70] & 902 & $\begin{array}{l}\text { Nab-paclitaxel +/- } \\
\text { atezolizumab }\end{array}$ & $\begin{array}{c}7.2 \text { vs. } 5.5 \mathrm{~m} \\
\text { HR } 0.80 \\
(0.69-0.92)\end{array}$ & $\begin{array}{c}21.3 \text { vs. } 17.6 \mathrm{~m} \\
\text { HR } 0.84 \\
(0.69-1.02)\end{array}$ \\
\hline Miles et al., 2021 [72] & 651 & $\begin{array}{l}\text { Paclitaxel +/- } \\
\text { atezolizumab }\end{array}$ & $\begin{array}{c}6.0 \text { vs. } 5.7 \mathrm{~m} \\
\text { HR } 0.82 \\
(0.60-1.12)\end{array}$ & $\begin{array}{c}22.1 \text { vs. } 28.3 \mathrm{~m} \\
\text { HR } 1.11 \\
(0.76-1.64)\end{array}$ \\
\hline Cortes et al., 2020 [74] & 847 & $\begin{array}{c}\text { Chemotherapy }+/- \\
\text { pembrolizumab }\end{array}$ & $\begin{array}{c}7.5 \text { vs. } 5.6 \mathrm{~m} \\
\text { HR } 0.82 \\
(0.69-0.97)\end{array}$ & \\
\hline Winer et al., 2021 [58] & 622 & $\begin{array}{l}\text { Pembrolizumab vs. } \\
\text { chemotherapy }\end{array}$ & & $\begin{array}{c}10.7 \text { vs. } 10.2 \mathrm{~m} \\
\text { HR } 0.86 \\
(0.69-1.06)\end{array}$ \\
\hline Tolaney et al., 2020 [75] & 88 & $\begin{array}{l}\text { Eribulin }+/- \\
\text { pembrolizumab }\end{array}$ & $\begin{array}{c}4.1 \text { vs. } 4.2 \mathrm{~m} \\
\text { HR } 0.80 \\
(0.50-1.26)\end{array}$ & $\begin{array}{c}13.4 \text { vs. } 12.5 \mathrm{~m} \\
\text { HR } 0.87 \\
(0.48-1.59)\end{array}$ \\
\hline
\end{tabular}

Abbreviations: HR, hazard ratio; ICPis, immune checkpoint inhibitors; ITT, intention to treat; m, months; OS, overall survival; PFS, progression-free survival; vs., versus. 


\subsection{ICPis in Early Breast Cancer}

As a result of the efficacy of ICPis in advanced breast cancer, trials have also been initiated in early TNBC. In a randomized phase II trial in early TNBC (GeparNuevo), the PD-L1 antibody durvalumab was combined with anthracycline- and taxane-containing neoadjuvant chemotherapy (NACT) in 174 TNBC patients [76]. In total, $87 \%$ of patients were PD-L1 positive. Pathological complete remission (pCR) was increased with durvalumab from $44.2 \%$ to $53.4 \%$. A significant increase in pCR was seen in the subgroup $(n=117)$ that received durvalumab neoadjuvantly for 2 weeks before starting NACT (61\% vs. $41.4 \%$; $p=0.035$ ). Immune-mediated thyroid dysfunction occurred in $47 \%$, with good overall tolerability. Interestingly, a preplanned exploratory analysis of this study showed that both tumor mutational burden (TMB) and immune gene expression profile (GEP) independently predicted $\mathrm{pCR}$ in TNBC patients [77]. In patients with high TMB and GEP, the $\mathrm{pCR}$ rate was $82 \%$ compared to $28 \%$ in the low TMB and GEP group. These results encourage further analysis of TMB in combination with immune parameters to tailor therapies in breast cancer. In GeparNuevo, Sinn and coworkers also examined mRNA signatures to predict response to neoadjuvant PD-L1 inhibition in combination with chemotherapy in early triple-negative breast cancer [78]. They found that immune-associated signatures related to antigen presentation and interferon signaling were associated with $\mathrm{pCR}$ after chemotherapy, but may be of limited utility in predicting response to additional immune checkpoint blockade. Recently, at the Annual Meeting of the American Society of Clinical Oncology, Loibl et al. presented the long-term survival results of GeparNuevo [79]. Of note, durvalumab was discontinued after surgery. As reported in the primary analysis, durvalumab failed to significantly increase pCR rates. However, 3-year iDFS was $84.9 \%$ with durvalumab versus $76.9 \%$ with placebo (HR 0.54, 95\% CI 0.27-1.09, $p=0.0559$ ), 3-year DDFS was $91.4 \%$ versus $79.5 \%$ (HR $0.37,95 \%$ CI $0.15-0.87, p=0.0148$ ), and 3-year OS was $95.1 \%$ versus $83.1 \%$ (HR $0.26,95 \% \mathrm{CI} 0.09-0.79, p=0.0076)$. The authors concluded that durvalumab as an adjunct to neoadjuvant chemotherapy in TNBC significantly improved long-term outcome despite a small increase in $\mathrm{PCR}$ and no continuation after surgery. They raised the obvious question of whether adjuvant therapy with ICPis is necessary at all. Furthermore, in addition to standard taxane- and anthracycline-based NACT, pembrolizumab was studied in the adaptive randomized phase II I-SPY trial [80]. In TNBC, pembrolizumab increased pCR from $22 \%$ to $60 \%$ with an acceptable safety profile.

In the neoadjuvant phase III KEYNOTE-522 trial, 1174 patients with early-stage TNBC were treated neoadjuvantly with anthracycline-, taxane-, and platinum-containing chemotherapy + / - pembrolizumab [81]. The addition of pembrolizumab significantly increased pCR from $51.2 \%$ to $64.8 \%(p=0.00055)$. This increase in $\mathrm{pCR}$ was observed regardless of PD-L1 status. In addition, pembrolizumab improved event-free survival (EFS) (HR $0.63 ; 95 \%$ CI $0.43-0.93$ ). Grade $3 / 4$ toxicities also occurred more frequently with pembrolizumab (78\% vs. $73 \%$ ). Recently, an updated version of this study was presented at the Annual Meeting of the European Society of Medical Oncology [82]. The authors confirmed improved EFS ( $84.5 \%$ vs. $76.8 \%$ ) and reported a strong trend towards longer OS (HR 0.72; 95\% CI 0.51-1.02).

The NeoTRIPaPDL1 Michelangelo randomized trial evaluated neoadjuvant nabpaclitaxel treatment with or without atezolizumab in triple-negative, early high-risk breast cancer and locally advanced breast cancer and failed to demonstrate a significant increase in pCR with atezolizumab [83]. Recently, however, results were presented on the efficacy and safety of atezolizumab compared with a placebo in combination with nab-paclitaxel followed by doxorubicin plus cyclophosphamide as a neoadjuvant treatment of early TNBC [84]. In total, 333 patients with early-stage TNBC were enrolled in the double-blind, randomized phase III IMpassion031 trial. Atezolizumab increased pCR from $41 \%$ to $58 \%$. In the PD-L1-positive population, pCR was increased from $49 \%$ to $69 \%$. Treatment-related serious adverse events occurred in $23 \%$ and $16 \%$ of cases, respectively. The authors concluded that neoadjuvant treatment with atezolizumab in combination with nab-paclitaxel and anthracycline-based chemotherapy improves PCR in early-stage TNBC patients and 
has an acceptable safety profile. The results of the phase III trials in early-stage TNBC are summarized in Table 4:

Table 4. Randomized evidence for ICPis in early triple-negative breast cancer.

\begin{tabular}{cccccc}
\hline Author & $n$ & Therapy & pCR in ITT & EFS in ITT & OS in ITT \\
\hline $\begin{array}{c}\text { Schmid et al., } \\
\text { 2020 [81]; ESMO 2021 [82] }\end{array}$ & 1174 & $\begin{array}{c}\text { Chemotherapy +/ } \\
\text { pembrolizumab }\end{array}$ & $64.8 \%$ vs. 51.2\% & $\begin{array}{c}\text { HR 0.63 } \\
0.43-0.93)\end{array}$ & $\begin{array}{c}\text { HR 0.72 } \\
(0.51-1.02)\end{array}$ \\
\hline $\begin{array}{c}\text { Mittendorf et al., } \\
\text { 2020 [84] }\end{array}$ & 333 & $\begin{array}{c}\text { Chemotherapy +/ } \\
\text { atezolizumab }\end{array}$ & $58 \%$ vs. 41 & $(0.40-1.44)$ \\
\hline $\begin{array}{c}\text { Gianni et al., SABCS 2019 } \\
\text { [83] }\end{array}$ & 280 & $\begin{array}{c}\text { Chemotherapy +/ } \\
\text { atezolizumab }\end{array}$ & $43.5 \%$ vs. 40.8\% & \\
\hline $\begin{array}{c}\text { Loibl et al., 2019 [76]; } \\
\text { ASCO 2021 [79] }\end{array}$ & 174 & $\begin{array}{c}\text { Chemotherapy +/ } \\
\text { durvalumab }\end{array}$ & 53.4 vs. 44.2 & HR 0.26 \\
\hline
\end{tabular}

Abbreviations: EFS, event-free survival; ESMO, European Society of Medical Oncology; HR, hazard ratio; ICPis, immune checkpoint inhibitors; ITT, intention to treat; m, months; OS, overall survival; pCR, pathologic complete response; SABCS, San Antonio Breast Cancer Symposium; vs., versus.

Indeed, the vast majority of randomized trials using ICPi in early or advanced TNBC showed significant benefits over standard therapy alone. When combined with an acceptable safety profile, immune checkpoint inhibitors are a promising new therapeutic option in TNBC. Recently, the Society for Immunotherapy of Cancer (SITC) published a clinical practice guideline on immunotherapy for breast cancer [85]. Recommendations in this clinical practice guideline include diagnostic testing, treatment planning, immunerelated adverse events, and patient quality of life considerations to provide guidance to the oncology community treating breast cancer patients with immunotherapies.

\section{Predictive Markers for Immune Checkpoint Inhibitors}

Currently, the only established predictive biomarker for response to ICPi in advanced TNBC is PD-L1 status. Recent analyses have shown a potential role of TMB in response to durvalumab in early TNBC [77]. In a recently published comprehensive genomic analysis of 3831 consecutive breast cancer samples, potential biomarkers (e.g., TMB, microsatellite instability [MSI], BRCA mutations) were assessed to guide the use of ICPIs in these patients [86]. Interferon- $\gamma$ (IFN- $\gamma$ ) plays a crucial role in the regulation of anti-tumor immunity [87]. Upon ligand binding, IFN-y receptor 1 and 2 (IFN $\gamma$ R1 and IFN $\gamma R 2$ ) oligomerize and transphosphorylate, activating Janus-activated kinase (JAK) 1 and 2. Thereby, IFN $\gamma$ R1 is phosphorylated, creating a docking site for the signal transducer and activator of transcription (STAT) 1 . Interferon- $\gamma$ (IFN- $\gamma$ ) signaling signatures are associated with clinical response to treatment with ICPi [88]. Similarly, JAK/STAT pathways predict response to ICPi therapy [89]. In addition, cancer stem cells are a potential biomarker to predict the effectiviness of ICPis [90]. However, for all of these potential biomarkers, prospective randomized trials are needed to assess the predictive value in response to immune checkpoint inhibitors.

\section{Adverse Events with Immune Checkpoint Inhibitors}

Adverse effects of ICPis are mainly explained by their mode of action. ICPis block so-called immune checkpoints, which act as "brakes" for triggered immune reactions. When this "brake" is blocked by antibodies, such as ICPis, an unrestrained immune response can occur, which can also attack the body's own tissues through autoimmune phenomena. This is associated with a spectrum of side effects related to the mechanism of action. The side effects can affect multiple organs of the body and most commonly occur in the skin, gastrointestinal tract, lungs, thyroid, adrenal, pituitary, kidney, nervous system, musculoskeletal system, eyes, or cardiovascular system. In addition to organ-specific side effects, infusion-related reactions such as fever, chills, shortness of breath, and sudden redness of the face, neck, or chest may occur [91-93] (Table 5). During treatment, it is 
important to note that these immune-mediated side effects may occur at widely varying intervals and sometimes even after cessation of therapy with ICPi.

Table 5. Immune-mediated adverse effects of immune checkpoint inhibitors.

\begin{tabular}{|c|c|c|}
\hline Organ & Occurrence with PD-(L)1 Inhibitors & Symptoms \\
\hline Brain & $\begin{array}{c}\text { Encephalitis }<1 \% \\
\text { Aseptic meningitis }<0.5 \%\end{array}$ & $\begin{array}{l}\text { Headache, changes in mental status, confusion, } \\
\text { depressed mood, sensitivity to light, seizures, motor or } \\
\text { sensory disturbances, meningitis, neck stiffness. }\end{array}$ \\
\hline Nerves & $\begin{array}{c}\text { Guillain- Barré } \\
\text { Syndrome }<0.5 \% \\
\text { Peripheral neuropathy } 16 \%\end{array}$ & $\begin{array}{l}\text { Muscle weakness (including eye muscles), fatigue, } \\
\text { difficulty swallowing, paresthesia or altered sensory } \\
\text { perception, ascending or progressive paralysis, } \\
\text { weakness of respiratory muscles. }\end{array}$ \\
\hline Skin & $\begin{array}{c}\text { Rash } 10 \% \\
\text { Pruritus } 15 \% \text { [93] }\end{array}$ & Persistent and/or severe skin rash or itching \\
\hline $\begin{array}{l}\text { Thyroid gland, adrenal } \\
\text { glands, pituitary gland, } \\
\text { islets of Langerhans of the } \\
\text { pancreas }\end{array}$ & $\begin{array}{c}\text { Hypothyroidism 8\% } \\
\text { Hyperthroidism 5\% } \\
\text { Adrenal insufficiency 1\% } \\
\text { Hypophysitis 1\% } \\
\text { Diabetes mellitus 1\% }\end{array}$ & $\begin{array}{c}\text { Fatigue, headache, changes in mental status, intolerance } \\
\text { to heat or cold, tachycardia or bradycardia, irregularity } \\
\text { in bowel movements, weight change, polyuria or } \\
\text { polydipsia, blurred vision. }\end{array}$ \\
\hline Lung & Pneumonitis $4 \%$ & $\begin{array}{l}\text { Difficulty breathing or coughing, radiographic changes } \\
\text { (e.g., focal morning opacity, patchy, patchy infiltrates), } \\
\text { dyspnea, hypoxia }\end{array}$ \\
\hline Liver & Hepatitis 5\% & $\begin{array}{l}\text { Increase in transaminases, increase in total bilirubin, } \\
\text { jaundice, right-sided abdominal pain, fatigue. }\end{array}$ \\
\hline Pancreas & Pancreatitis $3 \%$ & Abdominal pain, nausea, vomiting, and fever \\
\hline Intestine & Diarrhea/colitis $11 \%$ & $\begin{array}{l}\text { Watery, soft, or liquid stools; diarrhea; abdominal pain; } \\
\text { mucus or blood in the stool. }\end{array}$ \\
\hline
\end{tabular}

\section{Adverse Event Management}

Early diagnosis and therapy can reduce the severity and duration of immune-mediated adverse events. Proper management of these adverse events is, therefore, crucial. Depending on the severity of the side effects, different therapeutic measures are recommended. In case of marked worsening of symptoms, therapy with corticosteroids or even discontinuation of treatment with ICPi is required. (Table 6) [91].

Table 6. Treatment of adverse effects of immune checkpoint inhibitors.

\begin{tabular}{|c|c|}
\hline СТC & Actions \\
\hline I & Continue with close monitoring \\
\hline II & Discontinue therapy until improvement to grade 1 , consider corticosteroids if necessary \\
\hline III & $\begin{array}{l}\text { - } \quad \text { Administration of corticosteroids (prednisone } 1 \text { to } 2 \mathrm{mg} / \mathrm{kg} / \mathrm{d} \text { or methylprednisolone } 1 \text { to } 2 \mathrm{mg} / \mathrm{kg} / \mathrm{d} \text { ) } \\
\text { - }\end{array}$ \\
\hline IV & Termination of therapy (exception: endocrinopathies with improvement through hormone substitution) \\
\hline
\end{tabular}




\section{Vaccination}

The idea of using vaccines to boost the immune system against breast cancer has a long history [94]. Especially in cold tumors, there are few or no tumor-infiltrating lymphocytes. Possible reasons for this could be a lack of tumor antigens, a defect in antigen presentation, a lack of T-cell activation, and a deficit in homing to the tumor bed [95]. Vaccines may help to overcome this problem by improving the presentation of tumorassociated antigens, leading to a better immune response. Indeed, enhancing antigen presentation through vaccination is an obvious way to elicit a protective immune response against breast cancer. However, vaccination against solid tumors, such as breast cancer, has shown limited efficacy. In most cases, known antigens, such as HER2, have been used, but these vaccination strategies have shown only modest efficacy in breast cancer patients (Table 7) [96-99].

Table 7. Vaccination trials in breast cancer.

\begin{tabular}{cccccc}
\hline Author & $n$ & Setting & Vaccine & PFS & DFS \\
\hline Peoples et al., 2005 [96] & 53 & Adjuvant & E75 + GM-CSF & $85.7 \%$ vs. 59.8\% \\
\hline Disis et al., 2009 [99] & 22 & Advanced HER2+ & HER2 Th peptide + trastuzumab & 17.7 months & - \\
\hline Mittendorf et al., 2014 [98] & 187 & Adjuvant & E75 + GM-CSF & $\begin{array}{c}89.7 \% \text { vs. 80.2\% } \\
p=0.08\end{array}$ \\
\hline Mittendorf et al., 2016 [97] & 298 & Adjuvant & AE37 + GM-CSF & $-80.8 \%$ vs. 79.5\% \\
\end{tabular}

Abbreviations: DFS, disease-free survival; GM-CSF, granulocyte macrophage colony-stimulating factor; PFS, progression-free survival; Th, T helper; vs., versus.

However, a fundamental drawback of this approach is that immune responses against known self-antigens, such as HER2, are usually weak because T lymphocytes, which have a high affinity for these self-antigens, are subject to central tolerance. With the help of high-throughput mutation analysis techniques, such as next generation sequencing (NGS), single non-synonymous somatic mutations (the so-called mutanome) are increasingly coming into focus [100]. The resulting neoantigens are ideal for individual vaccination. Using complex computational prediction algorithms, the neoantigens with the highest expected immunogenicity are selected from the mutanome of a tumor. The mRNA of these neoantigens is then used as a vaccine [101]. The mRNAs are administered intravenously as a nano-particulate lipoplex formulation and are selectively delivered to splenic antigen-presenting cells. The encoded antigens are translated into proteins that are rapidly processed and presented as peptides on the surface of APCs, which, in turn, leads to the induction of antigen-specific T-cell responses [102].

While the focus of anti-tumor immunity research has long been on MHC I and CD8 T cells, it has been shown in mouse models that the majority of immunogenic mutations are presented via MHC II and recognized by CD4 T cells [103]. Meanwhile, the clinical efficacy of individual RNA vaccination against the individual mutanoma of a tumor in patients with advanced malignant melanome has been described [104].

Based on these encouraging results, the Mutanome Engineered RNA Immuno-Therapy (MERIT) project, a collaborative effort of partners from academia and industry, funded by the European Union's Seventh Framework Programme (FP7), aims to clinically and industrially validate a pioneering mRNA-based immunotherapy concept that targets individually expressed tumor antigens and tumor-specific mutations in patients with early TNBC. [102]. Before treatment, every patient's tumor will be profiled to select suitable shared tumor antigens (MERIT WAREHOUSE) and identify individual mutations (MERIT MUTANOME). Ideally, this approach will lead to a paradigm shift from stratified therapy targeting single common biomarkers, such as HER2, to fully individualized treatment targeting patientspecific mutations. As an integral part of the MERIT project, we have initiated a phase I 
study in early TNBC after completion of standard (neo)adjuvant chemotherapy [105]. TNBC-MERIT is a phase I study (NCT02316457) evaluating the feasibility, safety, and immunogenicity of a lipoplex-formulated intravenous mRNA vaccine encoding different tumor antigens in TNBC patients after surgery and (neo-)adjuvant chemotherapy. Patients in two arms of this study received a personalized set of pre-formulated, non-mutated, shared tumor-associated antigens (MERIT WAREHOUSE) with or without universal T helper epitopes. In a third arm, patients were inoculated with IVAC_M_uID, an on-demand individualized neoantigen-specific immunotherapy (iNeST) encoding neoepitopes derived from up to 20 cancer mutations identified by NGS (MERIT MUTANOME). The objective of this study was to demonstrate the feasibility, safety, and biological efficacy of a llipoplexformulated intavenous mRNA vaccine encoding different tumor antigens. Patients received eight intravenous vaccinations with either a personalized mRNA vaccine based on the antigen expression profile of each tumor (MERIT WAREHOUSE) or an individualized mRNA vaccine against up to 20 neoepitopes identified by NGS (MERIT MUTANOME). Recently, at the Annual Meeting of the European Society of Medical Oncology, we reported preliminary immune response data in IVAC_M_uID-vaccinated patients analyzed by interferon- $\gamma$ enzyme-linked-immuno-spot (IFN $\gamma$-ELISpot), T-cell receptor (TCR) profiling, and singlecell TCR sequencing [106]. Immunogenicity data were obtained from all 14 patients treated with IVAC_M_uID. All patients studied had vaccine-induced CD4+ and/or CD8+ T-cell responses against 1 to 10 of the vaccine neoepitopes detected by IFN $\gamma$-ELISpot ex vivo or after in vitro stimulation. A substantial number of T-cell responses against individual neoepitopes were induced de novo, of a high magnitude, and durable. One of the index patients characterized in more detail had CD4+ and/or CD8+ T-cell responses against 10 of 20 vaccine neoepitopes. The highly poly-epitopic TCR-clonotype diversified CD8+ T-cell response comprised, in aggregate, about 30\% of total peripheral CD8+ T cells and was sustained at high levels for more than 600 days after the last vaccination. This suggests that the individualized neoantigen-specific vaccine is highly efficient in inducing strong polyepitopic T-cell responses in patients with TNBC in the post-(neo)adjuvant phase. As an important effector cytokine for cancer immunity, IFN $\gamma$ also has prognostic and predictive significance in basal-like or triple-negative breast cancer, arguing for a protective effect of IFN $\gamma$-mediated immune responses by vaccination. [107,108].

With this vaccination strategy, T-cell responses against tumor-specific neoantigens can be induced. Such vaccines may lead to an increase in the immunogenicity of tumors that lack spontaneous immunogenicity, which should make these tumors more responsive to treatment with ICPis. Therefore, a combination of RNA vaccination and ICPis may be useful to stimulate the endogenous immune system against tumor cells, including in patients with prior ICPi experience [109]. Sahin and coworkers reported in this exploratory interim analysis of a phase I study that RNA vaccination is an effective immunotherapy in patients with ICPi-experienced melanoma, resulting in durable objective responses accompanied by the induction of strong CD4+ and CD8+ T-cell immunity to the vaccine antigens.

\section{Conclusions}

The immune system plays an important role in breast cancer. High expression of tumor-infiltrating lymphocytes or immune transcripts is associated with improved prognosis, as well as enhanced response to chemotherapy, especially in TNBC. Novel therapies, such as immune checkpoint inhibitors, have improved survival in triple-negative breast cancer. In addition, individualized vaccination strategies using mRNA vaccines against mutant tumor antigens are promising. Thus, a potentially rewarding future direction in the treatment of triple-negative breast cancer may be the combination of personalized vaccination and immune checkpoint inhibitors to fully harness the power of anti-tumor immunity. 
Author Contributions: Conceptualization, M.S. and A.-S.H.; writing-original draft, M.S. and A.S.H.; writing-review and editing, M.S. and A.-S.H. Both authors have read and agreed to the published version of the manuscript.

Funding: This research received no external funding.

Conflicts of Interest: M.S. reports personal fees from AstraZeneca, BioNTech, Eisai, Lilly, MSD, Novartis, Pantarhei Bioscience, Pfizer, Roche, and SeaGen. Institutional research funding from AstraZeneca, BioNTech, Eisai, Genentech, German Breast Group, Novartis, Palleos, Pantarhei Bioscience, Pierre-Fabre, and Roche. Travel reimbursement from Pfizer and Roche. In addition, M.S. is named as an inventor on patent EP 2390370 B1 and granted patent EP 2951317 B1. A.-S.H. reports no conflicts of interest.

\section{References}

1. Fitzmaurice, C.; Allen, C.; Barber, R.M.; Barregard, L.; Bhutta, Z.A.; Brenner, H.; Dicker, D.J.; Chimed-Orchir, O.; Dandona, R.; Dandona, L.; et al. Global, Regional, and National Cancer Incidence, Mortality, Years of Life Lost, Years Lived With Disability, and Disability-Adjusted Life-years for 32 Cancer Groups, 1990 to 2015: A Systematic Analysis for the Global Burden of Disease Study. JAMA Oncol. 2017, 3, 524-548. [CrossRef]

2. Burstein, H.J.; Curigliano, G.; Thürlimann, B.; Weber, W.P.; Poortmans, P.; Regan, M.M.; Senn, H.J.; Winer, E.P.; Gnant, M. Customizing local and systemic therapies for women with early breast cancer: The St. Gallen International Consensus Guidelines for treatment of early breast cancer 2021. Ann. Oncol. 2021, 32, 1216-1235. [CrossRef]

3. Cardoso, F.; Paluch-Shimon, S.; Senkus, E.; Curigliano, G.; Aapro, M.S.; André, F.; Barrios, C.H.; Bergh, J.; Bhattacharyya, G.S.; Biganzoli, L.; et al. 5th ESO-ESMO international consensus guidelines for advanced breast cancer (ABC 5). Ann. Oncol. 2020, 31, 1623-1649. [CrossRef]

4. Berg, J.W. Inflammation and prognosis in breast cancer; a search for host resistance. Cancer 1959, 12, 714-720. [CrossRef]

5. Iglesia, M.D.; Parker, J.S.; Hoadley, K.A.; Serody, J.S.; Perou, C.M.; Vincent, B.G. Genomic Analysis of Immune Cell Infiltrates Across 11 Tumor Types. J. Natl. Cancer Inst. 2016, 108, djw144. [CrossRef] [PubMed]

6. Metzger-Filho, O.; Tutt, A.; de Azambuja, E.; Saini, K.S.; Viale, G.; Loi, S.; Bradbury, I.; Bliss, J.M.; Azim, H.A., Jr.; Ellis, P.; et al. Dissecting the heterogeneity of triple-negative breast cancer. J. Clin. Oncol. 2012, 30, 1879-1887. [CrossRef] [PubMed]

7. Lehmann, B.D.; Bauer, J.A.; Chen, X.; Sanders, M.E.; Chakravarthy, A.B.; Shyr, Y.; Pietenpol, J.A. Identification of human triple-negative breast cancer subtypes and preclinical models for selection of targeted therapies. J. Clin. Investig. 2011, 121, 2750-2767. [CrossRef]

8. Thorsson, V.; Gibbs, D.L.; Brown, S.D.; Wolf, D.; Bortone, D.S.; Ou Yang, T.-H.; Porta-Pardo, E.; Gao, G.F.; Plaisier, C.L.; Eddy, J.A.; et al. The Immune Landscape of Cancer. Immunity 2018, 48, 812-830.e14. [CrossRef]

9. Wu, S.Z.; Al-Eryani, G.; Roden, D.L.; Junankar, S.; Harvey, K.; Andersson, A.; Thennavan, A.; Wang, C.; Torpy, J.R.; Bartonicek, N.; et al. A single-cell and spatially resolved atlas of human breast cancers. Nat. Genet. 2021, 53, 1334-1347. [CrossRef]

10. Narang, P.; Chen, M.; Sharma, A.A.; Anderson, K.S.; Wilson, M.A. The neoepitope landscape of breast cancer: Implications for immunotherapy. BMC Cancer 2019, 19, 200. [CrossRef]

11. Stanton, S.E.; Adams, S.; Disis, M.L. Variation in the Incidence and Magnitude of Tumor-Infiltrating Lymphocytes in Breast Cancer Subtypes: A Systematic Review. JAMA Oncol. 2016, 2, 1354-1360. [CrossRef] [PubMed]

12. Mosmann, T.R.; Cherwinski, H.; Bond, M.W.; Giedlin, M.A.; Coffman, R.L. Two types of murine helper T cell clone. I. Definition according to profiles of lymphokine activities and secreted proteins. J. Immunol. 1986, 136, 2348-2357. [PubMed]

13. Tuzlak, S.; Dejean, A.S.; Iannacone, M.; Quintana, F.J.; Waisman, A.; Ginhoux, F.; Korn, T.; Becher, B. Repositioning TH cell polarization from single cytokines to complex help. Nat. Immunol. 2021. [CrossRef] [PubMed]

14. Dunn, G.P.; Bruce, A.T.; Ikeda, H.; Old, L.J.; Schreiber, R.D. Cancer immunoediting: From immunosurveillance to tumor escape. Nat. Immunol. 2002, 3, 991-998. [CrossRef] [PubMed]

15. Emens, L.A. Breast Cancer Immunotherapy: Facts and Hopes. Clin. Cancer Res. 2018, 24, 511-520. [CrossRef]

16. Burugu, S.; Asleh-Aburaya, K.; Nielsen, T.O. Immune infiltrates in the breast cancer microenvironment: Detection, characterization and clinical implication. Breast Cancer 2016, 24, 3-15. [CrossRef]

17. Peng, G.-L.; Li, L.; Guo, Y.-W.; Yu, P.; Yin, X.-J.; Wang, S.; Liu, C.-P. CD8 $\left(^{+}\right)$cytotoxic and FoxP3 $\left({ }^{+}\right)$regulatory T lymphocytes serve as prognostic factors in breast cancer. Am. J. Transl. Res. 2019, 11, 5039-5053. [PubMed]

18. Mahmoud, S.M.A.; Paish, E.C.; Powe, D.G.; Macmillan, R.D.; Grainge, M.J.; Lee, A.H.S.; Ellis, I.O.; Green, A.R. Tumor-infiltrating CD8+ lymphocytes predict clinical outcome in breast cancer. J. Clin. Oncol. 2011, 29, 1949-1955. [CrossRef] [PubMed]

19. Denkert, C.; Loibl, S.; Noske, A.; Roller, M.; Müller, B.M.; Komor, M.; Budczies, J.; Darb-Esfahani, S.; Kronenwett, R.; Hanusch, C.; et al. Tumor-associated lymphocytes as an independent predictor of response to neoadjuvant chemotherapy in breast cancer. $J$. Clin. Oncol. 2010, 28, 105-113. [CrossRef]

20. Alexe, G.; Dalgin, G.S.; Scanfeld, D.; Tamayo, P.; Mesirov, J.P.; DeLisi, C.; Harris, L.; Barnard, N.; Martel, M.; Levine, A.J.; et al. High expression of lymphocyte-associated genes in node-negative HER2+ breast cancers correlates with lower recurrence rates. Cancer Res. 2007, 67, 10669-10676. [CrossRef] 
21. Rody, A.; Holtrich, U.; Pusztai, L.; Liedtke, C.; Gaetje, R.; Ruckhaeberle, E.; Solbach, C.; Hanker, L.; Ahr, A.; Metzler, D.; et al. T-cell metagene predicts a favorable prognosis in estrogen receptor-negative and HER2-positive breast cancers. Breast Cancer Res. 2009, 11, R15. [CrossRef]

22. Schmidt, M.; Bohm, D.; von Torne, C.; Steiner, E.; Puhl, A.; Pilch, H.; Lehr, H.-A.; Hengstler, J.G.; Kolbl, H.; Gehrmann, M. The humoral immune system has a key prognostic impact in node-negative breast cancer. Cancer Res. 2008, 68, 5405-5413. [CrossRef]

23. Bianchini, G.; Qi, Y.; Alvarez, R.H.; Iwamoto, T.; Coutant, C.; Ibrahim, N.K.; Valero, V.; Cristofanilli, M.; Green, M.C.; Radvanyi, L.; et al. Molecular anatomy of breast cancer stroma and its prognostic value in estrogen receptor-positive and -negative cancers. J. Clin. Oncol. 2010, 28, 4316-4323. [CrossRef]

24. Gentles, A.J.; Newman, A.M.; Liu, C.L.; Bratman, S.V.; Feng, W.; Kim, D.; Nair, V.S.; Xu, Y.; Khuong, A.; Hoang, C.D.; et al. The prognostic landscape of genes and infiltrating immune cells across human cancers. Nat. Med. 2015. [CrossRef] [PubMed]

25. Schmidt, M.; Hellwig, B.; Hammad, S.; Othman, A.; Lohr, M.; Chen, Z.; Boehm, D.; Gebhard, S.; Petry, I.; Lebrecht, A.; et al. A comprehensive analysis of human gene expression profiles identifies stromal immunoglobulin kappa $\mathrm{C}$ as a compatible prognostic marker in human solid tumors. Clin. Cancer Res. 2012, 18, 2695-2703. [CrossRef]

26. Nutt, S.L.; Tarlinton, D.M. Germinal center B and follicular helper T cells: Siblings, cousins or just good friends? Nat. Immunol. 2011, 12, 472-477. [CrossRef] [PubMed]

27. Schmidt, M.; Weyer-Elberich, V.; Hengstler, J.G.; Heimes, A.-S.; Almstedt, K.; Gerhold-Ay, A.; Lebrecht, A.; Battista, M.J.; Hasenburg, A.; Sahin, U.; et al. Prognostic impact of CD4-positive T cell subsets in early breast cancer: A study based on the FinHer trial patient population. Breast Cancer Res. 2018, 20, 15. [CrossRef] [PubMed]

28. Whiteside, T.L.; Ferrone, S. For breast cancer prognosis, immunoglobulin kappa chain surfaces to the top. Clin. Cancer Res. 2012, 18, 2417-2419. [CrossRef]

29. Schmidt, M.; Edlund, K.; Hengstler, J.G.; Heimes, A.-S.; Almstedt, K.; Lebrecht, A.; Krajnak, S.; Battista, M.J.; Brenner, W.; Hasenburg, A.; et al. Prognostic Impact of Immunoglobulin Kappa C (IGKC) in Early Breast Cancer. Cancers 2021, 13, 3626. [CrossRef]

30. Denkert, C.; von Minckwitz, G.; Brase, J.C.; Sinn, B.V.; Gade, S.; Kronenwett, R.; Pfitzner, B.M.; Salat, C.; Loi, S.; Schmitt, W.D.; et al. Tumor-infiltrating lymphocytes and response to neoadjuvant chemotherapy with or without carboplatin in human epidermal growth factor receptor 2-positive and triple-negative primary breast cancers. J. Clin. Oncol. 2015, 33, 983-991. [CrossRef] [PubMed]

31. Denkert, C.; von Minckwitz, G.; Darb-Esfahani, S.; Lederer, B.; Heppner, B.I.; Weber, K.E.; Budczies, J.; Huober, J.; Klauschen, F.; Furlanetto, J.; et al. Tumour-infiltrating lymphocytes and prognosis in different subtypes of breast cancer: A pooled analysis of 3771 patients treated with neoadjuvant therapy. Lancet Oncol. 2018, 19, 40-50. [CrossRef]

32. Loi, S.; Michiels, S.; Salgado, R.; Sirtaine, N.; Jose, V.; Fumagalli, D.; Kellokumpu-Lehtinen, P.-L.; Bono, P.; Kataja, V.; Desmedt, C.; et al. Tumor infiltrating lymphocytes are prognostic in triple negative breast cancer and predictive for trastuzumab benefit in early breast cancer: Results from the FinHER trial. Ann. Oncol. 2014, 25, 1544-1550. [CrossRef] [PubMed]

33. Edlund, K.; Madjar, K.; Lebrecht, A.; Aktas, B.; Pilch, H.; Hoffmann, G.; Hofmann, M.; Kolberg, H.-C.; Boehm, D.; Battista, M.; et al. Gene Expression-Based Prediction of Neoadjuvant Chemotherapy Response in Early Breast Cancer: Results of the Prospective Multicenter EXPRESSION Trial. Clin. Cancer Res. 2021, 27, 2148-2158. [CrossRef] [PubMed]

34. Adams, S.; Gray, R.J.; Demaria, S.; Goldstein, L.; Perez, E.A.; Shulman, L.N.; Martino, S.; Wang, M.; Jones, V.E.; Saphner, T.J.; et al. Prognostic value of tumor-infiltrating lymphocytes in triple-negative breast cancers from two phase III randomized adjuvant breast cancer trials: ECOG 2197 and ECOG 1199. J. Clin. Oncol. 2014, 32, 2959-2966. [CrossRef]

35. Loi, S.; Sirtaine, N.; Piette, F.; Salgado, R.; Viale, G.; van Eenoo, F.; Rouas, G.; Francis, P.; Crown, J.P.A.; Hitre, E.; et al. Prognostic and predictive value of tumor-infiltrating lymphocytes in a phase III randomized adjuvant breast cancer trial in node-positive breast cancer comparing the addition of docetaxel to doxorubicin with doxorubicin-based chemotherapy: BIG 02-98. J. Clin. Oncol. 2013, 31, 860-867. [CrossRef] [PubMed]

36. Ibrahim, E.M.; Al-Foheidi, M.E.; Al-Mansour, M.M.; Kazkaz, G.A. The prognostic value of tumor-infiltrating lymphocytes in triple-negative breast cancer: A meta-analysis. Breast Cancer Res. Treat. 2014, 148, 467-476. [CrossRef] [PubMed]

37. Hida, A.I.; Watanabe, T.; Sagara, Y.; Kashiwaba, M.; Sagara, Y.; Aogi, K.; Ohi, Y.; Tanimoto, A. Diffuse distribution of tumorinfiltrating lymphocytes is a marker for better prognosis and chemotherapeutic effect in triple-negative breast cancer. Breast Cancer Res. Treat. 2019, 178, 283-294. [CrossRef] [PubMed]

38. Liu, Z.; Li, M.; Jiang, Z.; Wang, X. A Comprehensive Immunologic Portrait of Triple-Negative Breast Cancer. Transl. Oncol. 2018, 11, 311-329. [CrossRef] [PubMed]

39. Karn, T.; Jiang, T.; Hatzis, C.; Sanger, N.; El-Balat, A.; Rody, A.; Holtrich, U.; Becker, S.; Bianchini, G.; Pusztai, L. Association Between Genomic Metrics and Immune Infiltration in Triple-Negative Breast Cancer. JAMA Oncol. 2017, 3, 1707-1711. [CrossRef]

40. Safonov, A.; Jiang, T.; Bianchini, G.; Gyorffy, B.; Karn, T.; Hatzis, C.; Pusztai, L. Immune Gene Expression Is Associated with Genomic Aberrations in Breast Cancer. Cancer Res. 2017, 77, 3317-3324. [CrossRef]

41. Salgado, R.; Denkert, C.; Demaria, S.; Sirtaine, N.; Klauschen, F.; Pruneri, G.; Wienert, S.; van den Eynden, G.; Baehner, F.L.; Penault-Llorca, F.; et al. The evaluation of tumor-infiltrating lymphocytes (TILs) in breast cancer: Recommendations by an International TILs Working Group 2014. Ann. Oncol. 2015, 26, 259-271. [CrossRef] 
42. Hendry, S.; Salgado, R.; Gevaert, T.; Russell, P.A.; John, T.; Thapa, B.; Christie, M.; van de Vijver, K.; Estrada, M.V.; GonzalezEricsson, P.I.; et al. Assessing Tumor-infiltrating Lymphocytes in Solid Tumors: A Practical Review for Pathologists and Proposal for a Standardized Method From the International Immunooncology Biomarkers Working Group: Part 1: Assessing the Host Immune Response, TILs in Invasive Breast Carcinoma and Ductal Carcinoma In Situ, Metastatic Tumor Deposits and Areas for Further Research. Adv. Anat. Pathol. 2017, 24, 235-251. [CrossRef]

43. Postow, M.A.; Callahan, M.K.; Wolchok, J.D. Immune Checkpoint Blockade in Cancer Therapy. J. Clin. Oncol. 2015, 33, 1974-1982. [CrossRef] [PubMed]

44. Ribas, A. Releasing the Brakes on Cancer Immunotherapy. N. Engl. J. Med. 2015, 373, 1490-1492. [CrossRef]

45. Swoboda, A.; Nanda, R. Immune Checkpoint Blockade for Breast Cancer. In Optimizing Breast Cancer Management; Gradishar, W.J., Ed.; Springer International Publishing: Cham, Switzerland, 2018; pp. 155-165. ISBN 978-3-319-70195-0.

46. Galon, J.; Bruni, D. Approaches to treat immune hot, altered and cold tumours with combination immunotherapies. Nat. Rev. Drug Discov. 2019, 18, 197-218. [CrossRef]

47. Adams, S.; Loi, S.; Toppmeyer, D.; Cescon, D.W.; de Laurentiis, M.; Nanda, R.; Winer, E.P.; Mukai, H.; Tamura, K.; Armstrong, A.; et al. Pembrolizumab monotherapy for previously untreated, PD-L1-positive, metastatic triple-negative breast cancer: Cohort B of the phase II KEYNOTE-086 study. Ann. Oncol. 2019, 30, 405-411. [CrossRef] [PubMed]

48. Cortés, J.; Lipatov, O.; Im, S.-A.; Gonçalves, A.; Lee, K.S.; Schmid, P.; Tamura, K.; Testa, L.; Witzel, I.; Ohtani, S.; et al. KEYNOTE119: Phase III study of pembrolizumab (pembro) versus single-agent chemotherapy (chemo) for metastatic triple negative breast cancer (mTNBC). Ann. Oncol. 2019, 30, v859-v860. [CrossRef]

49. Andre, F.; Dieci, M.V.; Dubsky, P.; Sotiriou, C.; Curigliano, G.; Denkert, C.; Loi, S. Molecular pathways: Involvement of immune pathways in the therapeutic response and outcome in breast cancer. Clin. Cancer Res. 2013, 19, 28-33. [CrossRef]

50. Zitvogel, L.; Apetoh, L.; Ghiringhelli, F.; Kroemer, G. Immunological aspects of cancer chemotherapy. Nat. Rev. Immunol. 2008, 8, 59-73. [CrossRef]

51. Emens, L.A.; Middleton, G. The interplay of immunotherapy and chemotherapy: Harnessing potential synergies. Cancer Immunol. Res. 2015, 3, 436-443. [CrossRef]

52. Park, H.J.; Kim, K.W.; Pyo, J.; Suh, C.H.; Yoon, S.; Hatabu, H.; Nishino, M. Incidence of Pseudoprogression during Immune Checkpoint Inhibitor Therapy for Solid Tumors: A Systematic Review and Meta-Analysis. Radiology 2020, 297, 87-96. [CrossRef]

53. Fuentes-Antrás, J.; Provencio, M.; Díaz-Rubio, E. Hyperprogression as a distinct outcome after immunotherapy. Cancer Treat. Rev. 2018, 70, 16-21. [CrossRef] [PubMed]

54. Borcoman, E.; Kanjanapan, Y.; Champiat, S.; Kato, S.; Servois, V.; Kurzrock, R.; Goel, S.; Bedard, P.; Le Tourneau, C. Novel patterns of response under immunotherapy. Ann. Oncol. 2019, 30, 385-396. [CrossRef] [PubMed]

55. Adams, S.; Schmid, P.; Rugo, H.S.; Winer, E.P.; Loirat, D.; Awada, A.; Cescon, D.W.; Iwata, H.; Campone, M.; Nanda, R.; et al. Pembrolizumab monotherapy for previously treated metastatic triple-negative breast cancer: Cohort A of the phase II KEYNOTE-086 study. Ann. Oncol. 2019, 30, 397-404. [CrossRef] [PubMed]

56. Emens, L.A.; Cruz, C.; Eder, J.P.; Braiteh, F.; Chung, C.; Tolaney, S.M.; Kuter, I.; Nanda, R.; Cassier, P.A.; Delord, J.-P.; et al. Long-term Clinical Outcomes and Biomarker Analyses of Atezolizumab Therapy for Patients With Metastatic Triple-Negative Breast Cancer: A Phase 1 Study. JAMA Oncol. 2019, 5, 74-82. [CrossRef]

57. Nanda, R.; Chow, L.Q.M.; Dees, E.C.; Berger, R.; Gupta, S.; Geva, R.; Pusztai, L.; Pathiraja, K.; Aktan, G.; Cheng, J.D.; et al. Pembrolizumab in Patients With Advanced Triple-Negative Breast Cancer: Phase Ib KEYNOTE-012 Study. J. Clin. Oncol. 2016, 34, 2460-2467. [CrossRef]

58. Winer, E.P.; Lipatov, O.; Im, S.-A.; Goncalves, A.; Muñoz-Couselo, E.; Lee, K.S.; Schmid, P.; Tamura, K.; Testa, L.; Witzel, I.; et al. Pembrolizumab versus investigator-choice chemotherapy for metastatic triple-negative breast cancer (KEYNOTE-119): A randomised, open-label, phase 3 trial. Lancet Oncol. 2021, 22, 499-511. [CrossRef]

59. Ge, Y.; Domschke, C.; Stoiber, N.; Schott, S.; Heil, J.; Rom, J.; Blumenstein, M.; Thum, J.; Sohn, C.; Schneeweiss, A.; et al. Metronomic cyclophosphamide treatment in metastasized breast cancer patients: Immunological effects and clinical outcome. Cancer Immunol. Immunother. 2012, 61, 353-362. [CrossRef]

60. Orecchioni, S.; Talarico, G.; Labanca, V.; Calleri, A.; Mancuso, P.; Bertolini, F. Vinorelbine, cyclophosphamide and 5-FU effects on the circulating and intratumoural landscape of immune cells improve anti-PD-L1 efficacy in preclinical models of breast cancer and lymphoma. Br. J. Cancer 2018, 118, 1329-1336. [CrossRef]

61. Falvo, P.; Orecchioni, S.; Hillje, R.; Raveane, A.; Mancuso, P.; Camisaschi, C.; Luzi, L.; Pelicci, P.; Bertolini, F. Cyclophosphamide and Vinorelbine Activate Stem-Like CD8+ T Cells and Improve Anti-PD-1 Efficacy in Triple-Negative Breast Cancer. Cancer Res. 2021, 81, 685-697. [CrossRef]

62. Khalifa, J.; Mazieres, J.; Gomez-Roca, C.; Ayyoub, M.; Moyal, E.C.-J. Radiotherapy in the Era of Immunotherapy with a Focus on Non-Small-Cell Lung Cancer: Time to Revisit Ancient Dogmas? Front. Oncol. 2021, 11, 662236. [CrossRef] [PubMed]

63. Voorwerk, L.; Slagter, M.; Horlings, H.M.; Sikorska, K.; van de Vijver, K.K.; de Maaker, M.; Nederlof, I.; Kluin, R.J.C.; Warren, S.; Ong, S.; et al. Immune induction strategies in metastatic triple-negative breast cancer to enhance the sensitivity to PD-1 blockade: The TONIC trial. Nat. Med. 2019, 25, 920-928. [CrossRef] [PubMed]

64. Peyraud, F.; Italiano, A. Combined PARP Inhibition and Immune Checkpoint Therapy in Solid Tumors. Cancers 2020, $12,1502$. [CrossRef] 
65. Domchek, S.M.; Postel-Vinay, S.; Im, S.-A.; Park, Y.H.; Delord, J.-P.; Italiano, A.; Alexandre, J.; You, B.; Bastian, S.; Krebs, M.G.; et al. Olaparib and durvalumab in patients with germline BRCA-mutated metastatic breast cancer (MEDIOLA): An open-label, multicentre, phase 1/2, basket study. Lancet Oncol. 2020, 21, 1155-1164. [CrossRef]

66. Adams, S.; Diamond, J.R.; Hamilton, E.; Pohlmann, P.R.; Tolaney, S.M.; Chang, C.-W.; Zhang, W.; Iizuka, K.; Foster, P.G.; Molinero, L.; et al. Atezolizumab Plus nab-Paclitaxel in the Treatment of Metastatic Triple-Negative Breast Cancer With 2-Year Survival Follow-up: A Phase 1b Clinical Trial. JAMA Oncol. 2019, 5, 334-342. [CrossRef] [PubMed]

67. Barroso-Sousa, R.; Krop, I.E.; Trippa, L.; Tan-Wasielewski, Z.; Li, T.; Osmani, W.; Andrews, C.; Dillon, D.; Richardson, E.T.; Pastorello, R.G.; et al. A Phase II Study of Pembrolizumab in Combination with Palliative Radiotherapy for Hormone Receptorpositive Metastatic Breast Cancer. Clin. Breast Cancer 2020, 20, 238-245. [CrossRef]

68. Pérez-García, J.M.; Llombart-Cussac, A.; Cortés, M.G.; Curigliano, G.; López-Miranda, E.; Alonso, J.L.; Bermejo, B.; Calvo, L.; Carañana, V.; de la Cruz Sánchez, S.; et al. Pembrolizumab plus eribulin in hormone-receptor-positive, HER2-negative, locally recurrent or metastatic breast cancer (KELLY): An open-label, multicentre, single-arm, phase II trial. Eur. J. Cancer 2021, 148, 382-394. [CrossRef] [PubMed]

69. Yuan, Y.; Lee, J.S.; Yost, S.E.; Frankel, P.H.; Ruel, C.; Egelston, C.A.; Guo, W.; Padam, S.; Tang, A.; Martinez, N.; et al. Phase I/II trial of palbociclib, pembrolizumab and letrozole in patients with hormone receptor-positive metastatic breast cancer. Eur. J. Cancer 2021, 154, 11-20. [CrossRef]

70. Schmid, P.; Adams, S.; Rugo, H.S.; Schneeweiss, A.; Barrios, C.H.; Iwata, H.; Dieras, V.; Hegg, R.; Im, S.-A.; Shaw Wright, G.; et al. Atezolizumab and Nab-Paclitaxel in Advanced Triple-Negative Breast Cancer. N. Engl. J. Med. 2018, 379, 2108-2121. [CrossRef]

71. Schmid, P.; Rugo, H.S.; Adams, S.; Schneeweiss, A.; Barrios, C.H.; Iwata, H.; Diéras, V.; Henschel, V.; Molinero, L.; Chui, S.Y.; et al. Atezolizumab plus nab-paclitaxel as first-line treatment for unresectable, locally advanced or metastatic triple-negative breast cancer (IMpassion130): Updated efficacy results from a randomised, double-blind, placebo-controlled, phase 3 trial. Lancet Oncol. 2020, 21, 44-59. [CrossRef]

72. Miles, D.; Gligorov, J.; André, F.; Cameron, D.; Schneeweiss, A.; Barrios, C.; Xu, B.; Wardley, A.; Kaen, D.; Andrade, L.; et al. Primary results from IMpassion131, a double-blind, placebo-controlled, randomised phase III trial of first-line paclitaxel with or without atezolizumab for unresectable locally advanced/metastatic triple-negative breast cancer. Ann. Oncol. 2021, 32, 994-1004. [CrossRef] [PubMed]

73. Franzoi, M.A.; de Azambuja, E. Atezolizumab in metastatic triple-negative breast cancer: IMpassion130 and 131 trials—How to explain different results? ESMO Open 2020, 5, 763. [CrossRef]

74. Cortes, J.; Cescon, D.W.; Rugo, H.S.; Nowecki, Z.; Im, S.-A.; Yusof, M.M.; Gallardo, C.; Lipatov, O.; Barrios, C.H.; Holgado, E.; et al. Pembrolizumab plus chemotherapy versus placebo plus chemotherapy for previously untreated locally recurrent inoperable or metastatic triple-negative breast cancer (KEYNOTE-355): A randomised, placebo-controlled, double-blind, phase 3 clinical trial. Lancet 2020, 396, 1817-1828. [CrossRef]

75. Tolaney, S.M.; Barroso-Sousa, R.; Keenan, T.; Li, T.; Trippa, L.; Vaz-Luis, I.; Wulf, G.; Spring, L.; Sinclair, N.F.; Andrews, C.; et al. Effect of Eribulin With or Without Pembrolizumab on Progression-Free Survival for Patients With Hormone Receptor-Positive, ERBB2-Negative Metastatic Breast Cancer: A Randomized Clinical Trial. JAMA Oncol. 2020, 6, 1598-1605. [CrossRef] [PubMed]

76. Loibl, S.; Untch, M.; Burchardi, N.; Huober, J.; Sinn, B.V.; Blohmer, J.-U.; Grischke, E.-M.; Furlanetto, J.; Tesch, H.; Hanusch, C.; et al. A randomised phase II study investigating durvalumab in addition to an anthracycline taxane-based neoadjuvant therapy in early triple-negative breast cancer: Clinical results and biomarker analysis of GeparNuevo study. Ann. Oncol. 2019, 30, 1279-1288. [CrossRef] [PubMed]

77. Karn, T.; Denkert, C.; Weber, K.E.; Holtrich, U.; Hanusch, C.; Sinn, B.V.; Higgs, B.W.; Jank, P.; Sinn, H.P.; Huober, J.; et al. Tumor mutational burden and immune infiltration as independent predictors of response to neoadjuvant immune checkpoint inhibition in early TNBC in GeparNuevo. Ann. Oncol. 2020, 31, 1216-1222. [CrossRef]

78. Sinn, B.V.; Loibl, S.; Hanusch, C.A.; Zahm, D.-M.; Sinn, H.-P.; Untch, M.; Weber, K.; Karn, T.; Becker, C.; Marmé, F.; et al. Immune-related Gene Expression Predicts Response to Neoadjuvant Chemotherapy but not Additional Benefit from PD-L1 Inhibition in Women with Early Triple-negative Breast Cancer. Clin. Cancer Res. 2021, 27, 2584-2591. [CrossRef]

79. Loibl, S.; Schneeweiss, A.; Huober, J.B.; Braun, M.; Rey, J.; Blohmer, J.U.; Furlanetto, J.; Zahm, D.M.; Hanusch, C.; Thomalla, J.; et al. Durvalumab improves long-term outcome in TNBC: Results from the phase II randomized GeparNUEVO study investigating neodjuvant durvalumab in addition to an anthracycline/taxane based neoadjuvant chemotherapy in early triple-negative breast cancer (TNBC). J. Clin. Oncol. 2021, 39, 506. [CrossRef]

80. Nanda, R.; Liu, M.C.; Yau, C.; Shatsky, R.; Pusztai, L.; Wallace, A.; Chien, A.J.; Forero-Torres, A.; Ellis, E.; Han, H.; et al. Effect of Pembrolizumab Plus Neoadjuvant Chemotherapy on Pathologic Complete Response in Women With Early-Stage Breast Cancer: An Analysis of the Ongoing Phase 2 Adaptively Randomized I-SPY2 Trial. JAMA Oncol. 2020, 6, 676-684. [CrossRef]

81. Schmid, P.; Cortes, J.; Pusztai, L.; McArthur, H.; Kümmel, S.; Bergh, J.; Denkert, C.; Park, Y.H.; Hui, R.; Harbeck, N.; et al. Pembrolizumab for Early Triple-Negative Breast Cancer. N. Engl. J. Med. 2020, 382, 810-821. [CrossRef]

82. Schmid, P.; Cortes, J.; Dent, R.; Pusztai, L.; McArthur, H.; Kümmel, S.; Bergh, J.; Denkert, C.; Park, Y.H.; Hui, R.; et al. VP7-2021: KEYNOTE-522: Phase III study of neoadjuvant pembrolizumab + chemotherapy vs. placebo + chemotherapy, followed by adjuvant pembrolizumab vs. placebo for early-stage TNBC. Ann. Oncol. 2019, 30 (Suppl. 5), v851-v934. [CrossRef] 
83. Gianni, L.; Huang, C.F.; Egle, D.; Bermejo, B.; Zamagni, C.; Thill, M.; Antonio, A.; Zambelli, S.; Bianchini, G.; Russo, S.; et al. Abstract GS3-04: Pathologic complete response (pCR) to neoadjuvant treatment with or without atezolizumab in triple negative, early high-risk and locally advanced breast cancer. NeoTRIPaPDL1 Michelangelo randomized study. In Proceedings of the 2019 San Antonio Breast Cancer Symposium, San Antonio, TX, USA, 10-14 December 2019.

84. Mittendorf, E.A.; Zhang, H.; Barrios, C.H.; Saji, S.; Jung, K.H.; Hegg, R.; Koehler, A.; Sohn, J.; Iwata, H.; Telli, M.L.; et al. Neoadjuvant atezolizumab in combination with sequential nab-paclitaxel and anthracycline-based chemotherapy versus placebo and chemotherapy in patients with early-stage triple-negative breast cancer (IMpassion031): A randomised, double-blind, phase 3 trial. Lancet 2020, 396, 1090-1100. [CrossRef]

85. Emens, L.A.; Adams, S.; Cimino-Mathews, A.; Disis, M.L.; Gatti-Mays, M.E.; Ho, A.Y.; Kalinsky, K.; McArthur, H.L.; Mittendorf, E.A.; Nanda, R.; et al. Society for Immunotherapy of Cancer (SITC) clinical practice guideline on immunotherapy for the treatment of breast cancer. J. Immunother. Cancer 2021, 9. [CrossRef] [PubMed]

86. Sivapiragasam, A.; Ashok Kumar, P.; Sokol, E.S.; Albacker, L.A.; Killian, J.K.; Ramkissoon, S.H.; Huang, R.S.P.; Severson, E.A.; Brown, C.A.; Danziger, N.; et al. Predictive Biomarkers for Immune Checkpoint Inhibitors in Metastatic Breast Cancer. Cancer Med. 2020, 10, 53-61. [CrossRef]

87. Castro, F.; Cardoso, A.P.; Gonçalves, R.M.; Serre, K.; Oliveira, M.J. Interferon-Gamma at the Crossroads of Tumor Immune Surveillance or Evasion. Front. Immunol. 2018, 9, 847. [CrossRef] [PubMed]

88. Grasso, C.S.; Tsoi, J.; Onyshchenko, M.; Abril-Rodriguez, G.; Ross-Macdonald, P.; Wind-Rotolo, M.; Champhekar, A.; Medina, E.; Torrejon, D.Y.; Shin, D.S.; et al. Conserved Interferon- $\gamma$ Signaling Drives Clinical Response to Immune Checkpoint Blockade Therapy in Melanoma. Cancer Cell 2020, 38, 500-515. [CrossRef]

89. Nishida, N. Role of Oncogenic Pathways on the Cancer Immunosuppressive Microenvironment and Its Clinical Implications in Hepatocellular Carcinoma. Cancers 2021, 13, 3666. [CrossRef]

90. Shi, X.; Liu, Y.; Cheng, S.; Hu, H.; Zhang, J.; Wei, M.; Zhao, L.; Xin, S. Cancer Stemness Associated With Prognosis and the Efficacy of Immunotherapy in Adrenocortical Carcinoma. Front. Oncol. 2021, 11, 651622. [CrossRef]

91. Brahmer, J.R.; Lacchetti, C.; Schneider, B.J.; Atkins, M.B.; Brassil, K.J.; Caterino, J.M.; Chau, I.; Ernstoff, M.S.; Gardner, J.M.; Ginex, P.; et al. Management of Immune-Related Adverse Events in Patients Treated With Immune Checkpoint Inhibitor Therapy: American Society of Clinical Oncology Clinical Practice Guideline. J. Clin. Oncol. 2018, 36, 1714-1768. [CrossRef]

92. Johnson, D.B.; Manouchehri, A.; Haugh, A.M.; Quach, H.T.; Balko, J.M.; Lebrun-Vignes, B.; Mammen, A.; Moslehi, J.J.; Salem, J.-E. Neurologic toxicity associated with immune checkpoint inhibitors: A pharmacovigilance study. J. Immunother. Cancer $2019,7,134$. [CrossRef]

93. Brahmer, J.R.; Abu-Sbeih, H.; Ascierto, P.A.; Brufsky, J.; Cappelli, L.C.; Cortazar, F.B.; Gerber, D.E.; Hamad, L.; Hansen, E.; Johnson, D.B.; et al. Society for Immunotherapy of Cancer (SITC) clinical practice guideline on immune checkpoint inhibitor-related adverse events. J. Immunother. Cancer 2021, 9, e002435. [CrossRef] [PubMed]

94. Zil'ber, L.A.; Baidakova, Z.L. Immunization against mouse mammary carcinoma. Vopr. Onkol. 1955, 1, 14-20. [PubMed]

95. Bonaventura, P.; Shekarian, T.; Alcazer, V.; Valladeau-Guilemond, J.; Valsesia-Wittmann, S.; Amigorena, S.; Caux, C.; Depil, S. Cold Tumors: A Therapeutic Challenge for Immunotherapy. Front. Immunol. 2019, 10, 168. [CrossRef] [PubMed]

96. Peoples, G.E.; Gurney, J.M.; Hueman, M.T.; Woll, M.M.; Ryan, G.B.; Storrer, C.E.; Fisher, C.; Shriver, C.D.; Ioannides, C.G.; Ponniah, S. Clinical trial results of a HER2/neu (E75) vaccine to prevent recurrence in high-risk breast cancer patients. J. Clin. Oncol. 2005, 23, 7536-7545. [CrossRef] [PubMed]

97. Mittendorf, E.A.; Ardavanis, A.; Symanowski, J.; Murray, J.L.; Shumway, N.M.; Litton, J.K.; Hale, D.F.; Perez, S.A.; Anastasopoulou, E.A.; Pistamaltzian, N.F.; et al. Primary analysis of a prospective, randomized, single-blinded phase II trial evaluating the HER2 peptide AE37 vaccine in breast cancer patients to prevent recurrence. Ann. Oncol. 2016, 27, 1241-1248. [CrossRef] [PubMed]

98. Mittendorf, E.A.; Clifton, G.T.; Holmes, J.P.; Schneble, E.; van Echo, D.; Ponniah, S.; Peoples, G.E. Final report of the phase I/II clinical trial of the E75 (nelipepimut-S) vaccine with booster inoculations to prevent disease recurrence in high-risk breast cancer patients. Ann. Oncol. 2014, 25, 1735-1742. [CrossRef]

99. Disis, M.L.; Wallace, D.R.; Gooley, T.A.; Dang, Y.; Slota, M.; Lu, H.; Coveler, A.L.; Childs, J.S.; Higgins, D.M.; Fintak, P.A.; et al. Concurrent trastuzumab and HER2/neu-specific vaccination in patients with metastatic breast cancer. J. Clin. Oncol. 2009, 27, 4685-4692. [CrossRef]

100. Castle, J.C.; Kreiter, S.; Diekmann, J.; Lower, M.; van de Roemer, N.; de Graaf, J.; Selmi, A.; Diken, M.; Boegel, S.; Paret, C.; et al. Exploiting the mutanome for tumor vaccination. Cancer Res. 2012, 72, 1081-1091. [CrossRef]

101. Tureci, O.; Vormehr, M.; Diken, M.; Kreiter, S.; Huber, C.; Sahin, U. Targeting the Heterogeneity of Cancer with Individualized Neoepitope Vaccines. Clin. Cancer Res. 2016, 22, 1885-1896. [CrossRef]

102. Mutanome Engineered RNA Immunotherapy (MERIT). Hum. Gene Ther. Clin. Dev. 2015, 26, 84-86. [CrossRef]

103. Kreiter, S.; Vormehr, M.; van de Roemer, N.; Diken, M.; Lower, M.; Diekmann, J.; Boegel, S.; Schrors, B.; Vascotto, F.; Castle, J.C.; et al. Mutant MHC class II epitopes drive therapeutic immune responses to cancer. Nature 2015, 520, 692-696. [CrossRef]

104. Sahin, U.; Derhovanessian, E.; Miller, M.; Kloke, B.-P.; Simon, P.; Lower, M.; Bukur, V.; Tadmor, A.D.; Luxemburger, U.; Schrors, B.; et al. Personalized RNA mutanome vaccines mobilize poly-specific therapeutic immunity against cancer. Nature 2017, 547, 222-226. [CrossRef] [PubMed] 
105. Schmidt, M.; Bolte, S.; Frenzel, K.; Heesen, L.; Derhovanessian, E.; Bukur, V.; Diken, M.; Gruetzner, J.; Kreiter, S.; Klein, A.; et al. Abstract OT2-06-01: Highly innovative personalized RNA-immunotherapy for patients with triple negative breast cancer. Cancer Res. 2019, 79, OT2-06. [CrossRef]

106. Schmidt, M.; Vogler, I.; Derhovanessian, E.; Omokoko, T.; Godehardt, E.; Attig, S.; Cortini, A.; Newrzela, S.; Grützner, J.; Bolte, S.; et al. $88 \mathrm{MO}$ T-cell responses induced by an individualized neoantigen specific immune therapy in post (neo)adjuvant patients with triple negative breast cancer. Ann. Oncol. 2020, 31, S276. [CrossRef]

107. Heimes, A.-S.; Härtner, F.; Almstedt, K.; Krajnak, S.; Lebrecht, A.; Battista, M.J.; Edlund, K.; Brenner, W.; Hasenburg, A.; Sahin, U.; et al. Prognostic Significance of Interferon- $\gamma$ and Its Signaling Pathway in Early Breast Cancer Depends on the Molecular Subtypes. Int. J. Mol. Sci. 2020, 21, 7178. [CrossRef] [PubMed]

108. Ademuyiwa, F.O.; Chen, I.; Luo, J.; Rimawi, M.F.; Hagemann, I.S.; Fisk, B.; Jeffers, G.; Skidmore, Z.L.; Basu, A.; Richters, M.; et al. Immunogenomic profiling and pathological response results from a clinical trial of docetaxel and carboplatin in triple-negative breast cancer. Breast Cancer Res. Treat. 2021, 189, 187-202. [CrossRef] [PubMed]

109. Sahin, U.; Oehm, P.; Derhovanessian, E.; Jabulowsky, R.A.; Vormehr, M.; Gold, M.; Maurus, D.; Schwarck-Kokarakis, D.; Kuhn, A.N.; Omokoko, T.; et al. An RNA vaccine drives immunity in checkpoint-inhibitor-treated melanoma. Nature 2020, 585, 107-112. [CrossRef] [PubMed] 